\title{
Biological evaluations of novel 2,3,3-Trisphosphonate in osteoclastic and osteoblastic activities
}

\author{
YK Cheong ${ }^{1 * * *}$, GG Ren ${ }^{1 * *}$, M Huang ${ }^{2}$, R Detsch ${ }^{3}$ and AR Boccaccini ${ }^{3}$ \\ ${ }^{1}$ School of Engineering and Technology, College Lane, University of Hertfordshire, Hatfield and AL10 9AB, UK \\ ${ }^{2}$ Institute of Dentistry, Barts and The London School of Medicine and Dentistry, Queen Mary University of London E1 2AD, UK \\ ${ }^{3}$ Institute of Biomaterials, Department of Materials Science and Engineering, University of Erlangen-Nuremberg, Cauerstr. 6, 91058 Erlangen, Germany \\ \#Authors contributed equally
}

\begin{abstract}
Bisphosphonates (BPs) are the first line treatment for many bone diseases including hypercalcimia associated with bone malignancies. In this paper, we introduce a new analogue of bisphosphonate called the 2,3,3-Trisphosphonate (2,3,3-TriPP) that was synthesised in a two steps reaction. In vitro investigations using a medically known bisphosphonate (Etidronate) and the 2,3,3-TrisPP were performed with an aim to evaluate biological effect of this novel compound in major bone cells. 2,3,3-TrisPP showed to have potential to supress the bone resorption process, as our data found that this novel compound exhibited cytotoxic effect in osteoclastic cells at a low concentration of $0.172 \mathrm{mg} / \mathrm{mL}\left(\mathrm{LC}_{50}\right)$. A molecular docking computational simulation calculated a high level of binding affinity between the human farnesyl pyrophosphate synthase (hFPPS) and 2,3,3-TrisPP. This calculation suggested 2,3,3TrisPP may have undergone the mevalonate pathway to prevent the prenylation step during biosynthesis and subsequently resulted in the deactivation of osteoclastic cells. Finally, high levels of osteoblast mineralisation potentials were recorded upon treatments with 2,3,3-TrisPP $(0.01-0.1 \mathrm{mg} / \mathrm{ml})$, which implied 2,3,3-TrsiPP may also facilitate bone regeneration.
\end{abstract}

\section{Introduction}

Bisphosphonate (BP) [1] is an important class of anti-resorptive medications for osteoporosis, [2] Paget's diseases, [3] hypercalcimia associated with bone metastasis [4-8] and other disorders involving excessive bone loss [9]. There are two classes of BP, the nitrogencontaining bisphosphonates (N-BP) and the non-nitrogen containing bisphosphonates (BP). These BP analogues exhibit excellent biodistributions on bone surface (hydroxyapatite) by chelating Calcium ions. Although the non-nitrogen BPs undergo cellular reaction to manipulate the ATP biosynthesis (Figure 1), while the N-BPs selectively bind to farnesylpyrophosphate synthase (FPPS) to inhibit the mevalonate pathway (Figure 2), both mechanisms eventually lead to suppression of the bone resorption process via inhibition of osteoclast activities [10-12]. Due to the selective inhibitory ability of N-BPs on the isoprenoid and cholesterol biosynthesis, extensive studies of BPs have been carried out to unveil their potential applications to other diseases related to Alzheimer's, immunomodulator and parasitological infections [13-16]. BPs are also known to own special metal-binding properties, [17] which has made great interests to scientists to explore
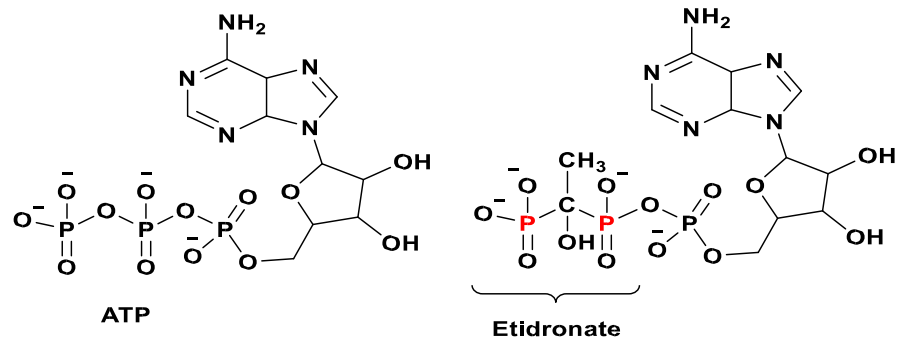

Figure 1. Chemical structures of ATP and its manipulated version after pyrophosphate group is replaced by a bisphosphonate group (e.g. Etidronate). the chemistry and metal conjugations of this category of compounds, $[18,19]$ in particular for the development in nuclear medicines $\left({ }^{186} \mathrm{Re}\right.$ therapy) [20] and radiopharmaceuticals ( ${ }^{99} \mathrm{Tc}$ imaging), [21-23] in advance material discoveries for bone and dental implants [24-26] as well as in nanotechnologies [27-29].

Evidence from preclinical models have shown that N-BPs are generally up to several orders of magnitude more potent than the conventional BPs at inhibiting bone resorption. However, the disadvantage of administering N-BPs is that patients are at risk of developing severe N-bisphosphonate-related osteonecrosis of the jaw (BRONJ) [30] and gastric inflammation [31-33]. Considering these adverse effects, nonnitrogen containing BPs (i.e. Clodronate) are still widely prescribed, especially to cancer patients who are in poor physical states [34,35].

There are over twenty clinically approved BPs on the market, many other derivatives have been synthesised, studied and reported [3638]. Griffiths, et al. have recently published a convenient method to synthesise a range of novel 2,3,3-trisphosphonates 2 (Figure 3), a new class of the non-nitrogen containing geminal BPs [39]. The synthesis of these 2,3,3-trisphosphonate derivatives $2\left(\mathrm{R}=\mathrm{Me}\right.$, Et or $\left.{ }^{i} \mathrm{Pr}\right)$ involve 'one-pot reactions' using 3,4-dihalogenated maleic anhydride and

Correspondence to: Yuen Ki Cheong, School of Engineering and Technology, College Lane, University of Hertfordshire, Hatfield and AL10 9AB, UK, E-mail: y.cheong2@herts.ac.uk

GG Ren, School of Engineering and Technology, College Lane, University of Hertfordshire, Hatfield and AL10 9AB, UK, E-mail: g.g.ren@herts.ac.uk

Received: November 14, 2017; Accepted: December 04, 2017; Published: December 08, 2017 


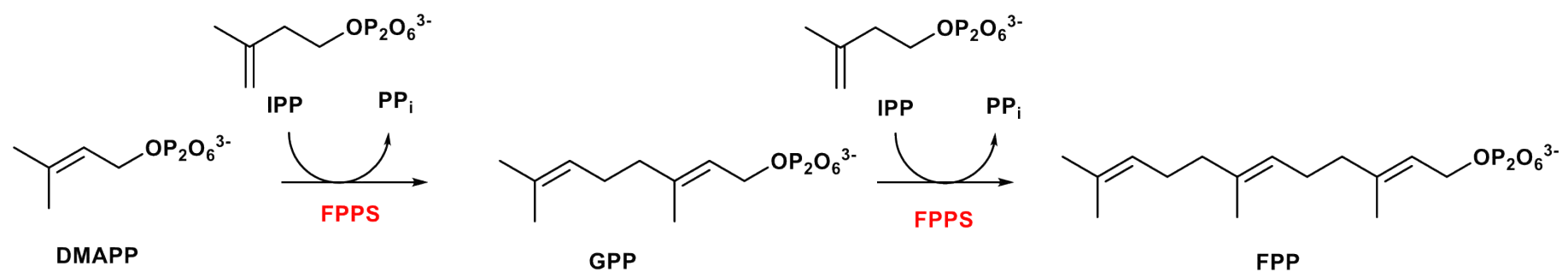

Figure 2. The Mevalonate pathway: FPPS is required to catalyse the twostep synthesis of farnesyl pyrophosphate (FPP) and garanyl diphosphate (GPP) for osteoclast function and viability.

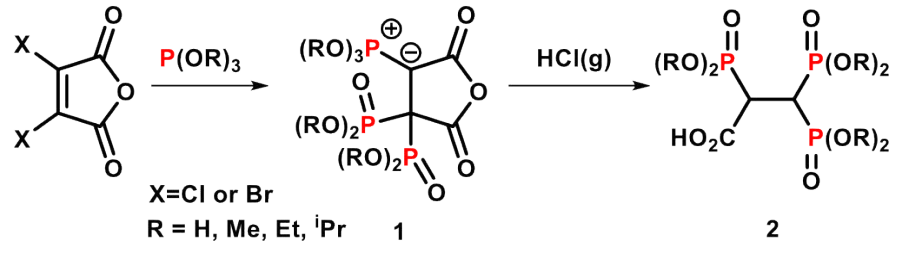

Figure 3. Synthetic approach for trisphosphonic ester 2 (precursor of 2,3,3-TrisPP).

three equivalents of trialkylphosphite at ambient temperature. These reactions give initially ylidic bisphosphonates $1\left(\mathrm{R}=\mathrm{Me}\right.$, Et or $\left.{ }^{i} \mathrm{Pr}\right)$ as stable intermediates, which subsequently undergo protonation to give the ring opened trisphosphonic esters $2\left(\mathrm{R}=\mathrm{Me}\right.$, Et or $\left.{ }^{i} \mathrm{Pr}\right)$. A complete hydrolysis of the trisphosphosphic ester $2(\mathrm{R}=\mathrm{Et})$ under acid condition gives the desired 2,3,3-TrisPP (Figure 4), the compound that was used in this biological report.

The first biological study of the 2,3,3-TrisPP reported by Yang, et al. who has revealed the intercellular $\mathrm{Ca}^{2+}$ binding ability of this novel system in a neurocellular research. 2,3,3-TrisPP was found to chelate with $\mathrm{Ca}^{2+}$ ions intercellularly, which had led to neuro-protective effects in PC12 cells via mechanisms involving $\mathrm{Ca}^{2+}$ attenuation and oxidative stress relief [40]. With regard to the chemical structure relationship, 2,3,3-TrisPP shares a common feature to all typical BPs (i.e. Etidronate), it contains a geminal bisphosphonate unit (PC$\mathrm{P})$ where the two phosphonic acid groups share the same $\alpha$-carbon atom [41]. Besides, this novel 2,3,3TrisPP owns an extra phosphoryl unit, locates in very close proximity to the germinal BP moiety. The present of this additional phosphoryl unit is expected to enhance functionalities, pharmacokinetic and antiresorptive effects in bones, as well as to ameliorate adverse effects and complications cause by current NBP treatments.

\section{Materials and methods}

\section{Chemicals and reagents}

Organic solvents such as dichloromethane, acetone, acetonitrile, ethyl acetate etc, were purchased from VWR. TLC was performed with alumina backed silica gel 60 F254 eluting with the solvent system used for the column chromatography and the plates were visualised under UV light or developed in an iodine tank. Column chromatography used silica gel with particle size $33-50 \mu \mathrm{m}$ and was purchased from $\mathrm{BDH}$. All other materials including dichloromaleic anhydride and triethylphosphite were purchased from Sigma-Aldrich. All other chemicals were used as received unless otherwise indicated.

\section{Preparation of 2,3,3-TrisPP in situ}

Triethylphosphite $(2.98 \mathrm{~g}, 18 \mathrm{mmol})$ in a syringe was added dropwise into a stirred solution of dichloromaleic anhydride (1 g, 5.9 $\mathrm{mmol})$ and dried dichloromethane $(15 \mathrm{~mL})$ through a lose septum over a period of 15 minutes. The resulting reaction mixture was then allowed<smiles>O=PC(C(C(=O)O)[PH](=O)O)P(=O)(O)O</smiles>

2,3,3-TrisPP<smiles>CC(O)(P(=O)=O)P(=O)(O)O</smiles>

Etidronate
Figure 4. Chemical structures of 2,3,3-TrisPP and Etidronate (a clinical BP).

to stir under a sealed condition at room temperature for a further 16 hours. This crude ylidic bisphosphonate 1 was then purified by silica gel chromatography using a gradient solvent of dichloromethane and acetonitrile mixtures as eluent. Chromatography fractions were analysed using silica based tlc plate, which was developed using $100 \%$ acetonitrile as mobile phase solvent system and then visualised under UV light to determine present of ylidic bisphosphonate 1 collected. Volatile components of the collected chromatography fractions were removed under reduced pressure $\left(55^{\circ} \mathrm{C}\right.$ at $\left.10 \mathrm{mmHg}\right)$, NMR spectra of the obtained green oil confirmed ylidic bisphosphonate was formed in a high state of purity [39]. A stream of dry Hydrogen Chloride gas was bubbled into this freshly prepared ylidic bisphosphonate 1 in dichloromethane $(20 \mathrm{~mL})$ over a period of 20 minutes, this homogeneous solution was stirred for a further 1 hour before volatile components were removed under reduced pressure $\left(35^{\circ} \mathrm{C}\right.$ at 10 $\mathrm{mmHg}$ ). The residue was then re-dissolved into $20 \mathrm{~mL}$ of aqueous acetonitrile (1:1 ratio) and stirred at room temperature overnight. Crude 2,3,3-TrisPP was obtained as pale-yellow oil after removal of volatile components in vacuo. This sample was firstly isolated via solvent extraction using dichloromethane and water mixtures. Water layers were collected and combined, volatile components were then removed in vacuo $\left(45^{\circ} \mathrm{C}\right.$ at $\left.0.01 \mathrm{mmHg}\right)$, residue was subsequently washed and triturated from initially DCM and then ethyl acetate multiple times. A pure sample of 2,3,3-TrisPP $(0.8 \mathrm{~g}, 45 \%)$ was finally obtained as colourless solid after removing excess water under reduced pressure. Original method and analytic data of 2,3,3-TrisPP had been previously reported by Griffiths, et al.

\section{NMR characterisation of 2,3,3-TrisPP}

NMR spectra were recorded on a JEOL EX-600 spectrometer located at the Department of Pharmacy, University of Hertfordshire. Chemical shifts are reported in 'ppm' whereas coupling constants ( $J$ values) are measured in Hertz. Etidronate (Etidronic acid) was purchased from Sigma-Aldrich, while 2,3,3-TrisPP as prepared in situ, both samples were dissolved in $\mathrm{D}_{2} \mathrm{O}$ (Goss Scientific Ltd.) and all NMR experiments performed using $5 \mathrm{~mm}$ diameter NMR glass tubes. Hydrogen resonances $\left(\delta_{\mathrm{H}} 5.30 \mathrm{ppm}\right)$ present in residual water in samples were irradiated and suppressed during all ${ }^{1} \mathrm{H}$ NMR acquisitions. NMR data set were recorded using Dalta and the resulting spectra were processed using MestRe Nova. NMR spectra of Etidronate and 2,3,3-TrisPP can be found in supplementary files provided. $\dagger 31 P$ 
NMR of 2,3,3-TrisPP (243 MHz; D O) $\delta 17.09$ (br s, P-C), 18.50 (2 P, br s, P-C-P); 13C NMR of 2,3,3-TrisPP (150.9 MHz, $\left.\mathrm{D}_{2} \mathrm{O}\right) \delta 37.4\left(\mathrm{t}, J_{\mathrm{PC}} 123\right.$ $\mathrm{Hz}, \mathrm{P}-\mathrm{C}-\mathrm{P}), 43.7$ (dt, $J_{\mathrm{PC}} 118$ \& $\left.18 \mathrm{~Hz}, \mathrm{P}-\mathrm{C}\right), 170.9\left(\mathrm{CO}_{2} \mathrm{H}\right) .1 \mathrm{H} \mathrm{NMR}$ of 2,3,3-TrisPP $\left(400 \mathrm{MHz}, \mathrm{D}_{2} \mathrm{O}\right) \delta 2.35\left(1 \mathrm{H}, \mathrm{tdd}, J_{\mathrm{PH}} 24 \& 12 \mathrm{~Hz}, J_{\mathrm{HH}} 3 \mathrm{~Hz}\right.$, $\left.\mathrm{P}_{2} \mathrm{CH}\right), \delta 2.90(1 \mathrm{H}, \mathrm{m}, \mathrm{PCH})$.

\section{Osteoclast in vitro assay}

\section{Cell culture}

RAW 264.7 cells (purchased from ATCC), are mouse leukaemic monocyte-macrophage cell line. It was incubated in a minimal essential medium (Gibco) with 10 vol.\% fetal calf serum (FCS), which was then stimulated using macrophage colony-stimulating factor (M-CSF, $5 \mathrm{ng} /$ $\mathrm{ml}$, Biochrom) and receptor activator of the NFKB ligand (RANKL, 40 $\mathrm{ng} / \mathrm{ml}$, Biochrom) for 14 day. These factors induced the differentiation of the monocytes-macrophages into osteoclast-like cells. $\dagger$ In vitro experiments were then carried out by treating these osteoclast-like cells using different concentrations of Etidronates or 2,3,3TrisPP for 24 hours prior assessments. Identification of Osteoclatic cells

Cell morphology of the affected cells was studied by light microscope (Axiovert, Zeiss, Germany). Investigations of Tartrateresistant acid phosphatase (TRAP) activities of RAW 264.7 cells were performed using TRAP ELF 97 (Molecular Probes ${ }^{\circledR}$ ) whereas the cells were stained with Phalloidin and DAPI (Molecular Probes ${ }^{\star}$ ) and observed under fluorescence microscope (AxioVert Zeiss, Germany) to investigate the actin ring expression.

\section{Cell viability}

WST-8 assay (Sigma-Aldrich), a CCk-8 cell counting kit was used to assess the viability of the cultivated cells.

Osteoclast-like cells were treated with different concentrations (0.01-2 mg/mL) of Etidronate and 2,3,3TrisPP for 24 hours. Culture media was removed from the cell culture wells plates and the cells were washed twice with PBS. After addition of CCK-8 solution in each well, the plates were incubated for 1 hour to allow conversion of tetrazolium to an orange formazan product by mitochondrial enzymes (cellular dehydrogenases). Finally, the solution was seeded in a 96-well plate, mitochondrial activities were measured by colorimetric assay using a spectrophotometer (Phomo, Anthos Mikrosysteme GmbH, Germany). The intensities of absorbance $\left(\lambda_{\text {abs }} 450 \mathrm{~nm}\right)$ of the affected osteoclastlike cells were measured, the mitochondrial activities and the number of viable cells in the cytotoxic assay were also calculated.

\section{Quantification analysis}

For statistical analysis of the differences of the mitochondrial activity, the one-way analysis of variance (ANOVA) was used, which is implemented in Origin 9G software (OriginLab Corporations, USA). The number of samples was $\mathrm{N}=6$ for the mitochondrial activity and for the morphological studies. The significance level was set as $\mathrm{p}<0.05=*$, $\mathrm{p}<0.01={ }^{* *}$ and $\mathrm{p}<0.001={ }^{* * *}$. For the comparison of the mean values the Tukey test was used. $\mathrm{LC}_{50}$ value (lethal concentration of the used solution where the activity of the cells is reduced to $50 \%$ ) was calculated.

\section{Molecular protein-ligand docking simulation}

Docking calculations were carried out using DockingServer [42]. Gasteiger partial charges were added to the ligand atoms. Non-polar hydrogen atoms were merged, and rotatable bonds were defined. Docking calculations were carried out on TrisPP-hFPPS model, where 2,3,3-TrisPP ligand was generated by ChemBioDraw ultra 13.0 and the macromolecule of human FPPS was downloaded from the RCSB Protein Data Bank as an un-liganded protein (2F7M) [41]. Essential hydrogen atoms, Kollman united atom type charges, and solvation parameters were added with the aid of AutoDock tools [43]. Affinity (grid) maps of $40 \times 25 \times 30 \AA$ grid points and $0.375 \AA$ spacing were generated using the Autogrid program. AutoDock parameter set- and distance-dependent dielectric functions were used in the calculation of the van der Waals and the electrostatic terms, respectively. Docking simulations were performed using the Lamarckian genetic algorithm (LGA) and the Solis \& Wets local search method [44]. Initial position, orientation, and torsions of the 2,3,3-TrisPP molecules were set randomly. All rotatable torsions were released during docking. Each docking experiment was derived from 100 different runs that were set to terminate after a maximum of 2500000 energy evaluations. The population size was set to 150 . During the search, a translational step of $0.2 \AA$, quaternion and torsion steps of 5 were applied.

\section{Osteoblast in vitro assay}

Cell culture: MC3T3-E1 cells (purchased from ATCC) were cultured in a-MEM (Lonza, Switzerland) supplemented with $10 \%$ fetal bovine serum (FBS) and antibiotics (10U/L penicillin and $100 \mathrm{mg} / \mathrm{L}$ streptomycin) in a humidified atmosphere containing $10 \% \mathrm{CO}_{2}$ at $37^{\circ} \mathrm{C}$ and the medium changed every two days. Cells were seeded in 96-wells plates (1000 cells/well) for proliferation assay and ALP activity assay.

\section{Cell proliferation assay}

Total DNA content was measured to quantify the cellular proliferation as previously described [45]. Briefly, the cells were collected $1,4,7$, and 10 days after 2,3,3-TrisPP $(0,0.01,0.1$ and 0.5 $\mathrm{mg} / \mathrm{ml}$ ) treatment and stored at $-20^{\circ} \mathrm{C}$. With all time points collected, cells were thawed at room temperature and $100 \mu$ ldistilled water was added to each well then refrozen. After $24 \mathrm{hrs}$ thawed again and $100 \mu \mathrm{l}$ of the fluorochrome Hoechst 33258 at the concentration $20 \mu \mathrm{g} / \mathrm{ml}$ in high salt TNE buffer $(2 \mathrm{M} \mathrm{NaCl})$ was added to each well. The plates were read with excitation at $\lambda 350 \mathrm{~nm}$ and emission at $\lambda 460 \mathrm{~nm}$. Cell number was calculated according to the cell number standard curve. The results were collected from three independent experiments.

\section{Differentiation assay}

To determine the early 2,3,3-TrisPP induced differentiation of MC3T3-E1 cells, ALP activity was assessed. Sample collection and preparation was the same as cell proliferation assay. After that $100 \mu \mathrm{l}$ ALP reaction solution (20mg 4-Nitropheyl-phosphate disodium salt hexahydrate tablet was dissolved in $8 \mathrm{ml} 2,3,3$-TrisPP buffer solution $(\mathrm{pH}=9.5)$ containing $15 \mu \mathrm{l}$ of $2 \mathrm{M} \mathrm{MgCl}_{2}$ ) was added to cell lysate, incubated in $37^{\circ} \mathrm{C}$ for $1 \mathrm{hr}$., then pNP formation was measured at 405 $\mathrm{nm}$ with a spectrophotometer. ALP activity was calculated according to the standard curve and normalised by cell number. Experiments were performed three times.

\section{Mineralisation}

For Alizarin Red S staining, 24-wells plates were used with $5 \times 10^{3}$ cells/well cultured. Cells were treated with osteogenic differentiation medium (OM, containing 10\% FBS, 50 $\mathrm{g} / \mathrm{ml} \mathrm{L}$-ascorbic acid, $5 \mathrm{mM}$ $\beta$ glycerophosphate and $10 \mathrm{nM}$ dexamethasone) for mineralisation study. After 3, 4 and 5 weeks, the cells were washed with PBS and fixed in $4 \%$ glutaraldehyde for $30 \mathrm{~min}$, then stained with $2 \%$ Alizarin Red S (Sigma-Aldrich, St Louis, MO, USA) for $1 \mathrm{hr}$ at room temperature, after that they were washed three times with distilled water to remove unbound stain, and air-dried before being photographed. For quantification, stain was extracted with $10 \%$ cetylpyridinum chloride in 
deionized water, and then incubated for $1 \mathrm{hr}$. at the room temperature, and then the absorbance of the supernatant was measured at $560 \mathrm{~nm}$. The data were collected from three same conditioned wells.

\section{Results}

\section{General}

2,3,3-TrisPP as shown in figure 4 was synthesised and isolated in situ using a modification procedure of Griffith, et al. (Figure 3) [39]. A more established purification method is indeed reported herein, the chemical structure and purity of the 2,3,3-TrisPP was assessed by ${ }^{31} \mathrm{P}$, ${ }^{13} \mathrm{C}$ and ${ }^{1} \mathrm{H}$ NMR spectroscopes. $\dagger$ Synthetic $2,3,3$-TrisPP was dissolved in purified water prior all biological testing. ${ }^{\dagger}$ With an aim to examine biological activities of 2,3,3-TrisPP in major bone cells, differentiated osteoclastic (RAW264.7) [46,47] and preosteoblastic (MC3T3-E1) [48] cell-lines were employed in our in vitro studies. Parallel studies using commercially available Etidronate were performed to enable comparison in their biological effects [49] and standard evaluations of novel 2,3,3-TrisPP.

\section{In vitro osteoclast assay}

\section{TRAP and Actin Ring expression}

Cytotoxic effects in osteoclastic cells induced by different concentrations $(0.01-2 \mathrm{mg} / \mathrm{ml})$ of Etidronate and 2,3,3-TrisPP were initially assessed by microscopic imaging. ' Selective images from cell morphology studies showed cell fragments of the differentiated RAW264.7 culture after it was exposed to $0.5 \mathrm{mg} / \mathrm{ml}$ of Etidronate (Figure 5a) and 2,3,3-TrisPP (Figure 5b) for 24 hours. A remarkable decrease in number of cells was observed when cells were exposed to 2,3,3-TrisPP (Figure 5b). To study the cell behaviour of these affected cultures, actin ring characterisation was carried out using Phalloidin/
DAPI staining protocol. (Figure $5 \mathrm{c})(0.5 \mathrm{mg} / \mathrm{ml}$ Etidronate) and (Figure 5d) $(0.5 \mathrm{mg} / \mathrm{ml} \mathrm{2,3,3-TrisPP})$ showed selective fluorescent images $\dagger$ of nuclei counterstained with DAPI (blue) while actin filaments were stained with Phalloidin (red). To identify TRAP activities in the affected osteoclastic cells, a histochemical staining method was performed using fluorescent-based ELF97 substrates. (Figure 5e) and (figure 5f) showed selective fluorescent images $\dagger$ of TRAP expression after osteoclastic cells were exposed to $0.5 \mathrm{mg} / \mathrm{ml}$ of Etidronate and 2,3,3-TrisPP respectively. An obvious cytotoxic effect was observed from both TRAP and actin ring studies after osteoclast-like cells were incubated in $0.5 \mathrm{mg} / \mathrm{ml}$ of $2,3,3$-TrisPP at $37^{\circ} \mathrm{C}$ for 24 hours. In contrast, almost $2 \mathrm{mg} / \mathrm{ml}$ of Etidronate was required to exhibit a level of toxic effect in the osteoclast-like cell cultures.

\section{Cell viabilities and $\mathrm{LC}_{50}$}

Cell viability of the osteoclastic cells were assessed by WST-8 assay to determine the lethal concentrations $\left(\mathrm{LC}_{50}\right)$ required from Etidronate and 2,3,3-TrisPP to reduce the cell viability by half. A trend of decreasing in cell numbers was observed (Figure 6a) when osteoclastic cultures were treated with Etidronate and 2,3,3TrisPP at various concentrations $(0.01-2 \mathrm{mg} / \mathrm{ml})$ for 24 hours. Figure $6 \mathrm{~b}$ indicates normalised results of cell vitality (\%), while $0.01-0.1 \mathrm{mg} / \mathrm{ml}$ of Etidronate did not induce any cytotoxic effect on the osteoclast-like cells, 2,3,3-TrisPP treatments showed immediate cell necrosis by 6.3 and $30 \%$ at the same concentrations. As $0.5-1 \mathrm{mg} / \mathrm{ml}$ of Etidronate treatments began to show a reduction in cell numbers by $15-40 \%$, 2,3,3-TrisPP efficiently suppressed osteoclastic mitochondrial activities by over $90 \%$ at the same concentration. Finally, the rates of cell viability were measured and the corresponding $\mathrm{LC}_{50}$ for Etidronate and 2,3,3-TrisPP in osteoclastic cells were subsequently calculated as 1.25 and $0.172 \mathrm{mg} / \mathrm{ml}$ respectively (Figure $6 \mathrm{~b}$ ).
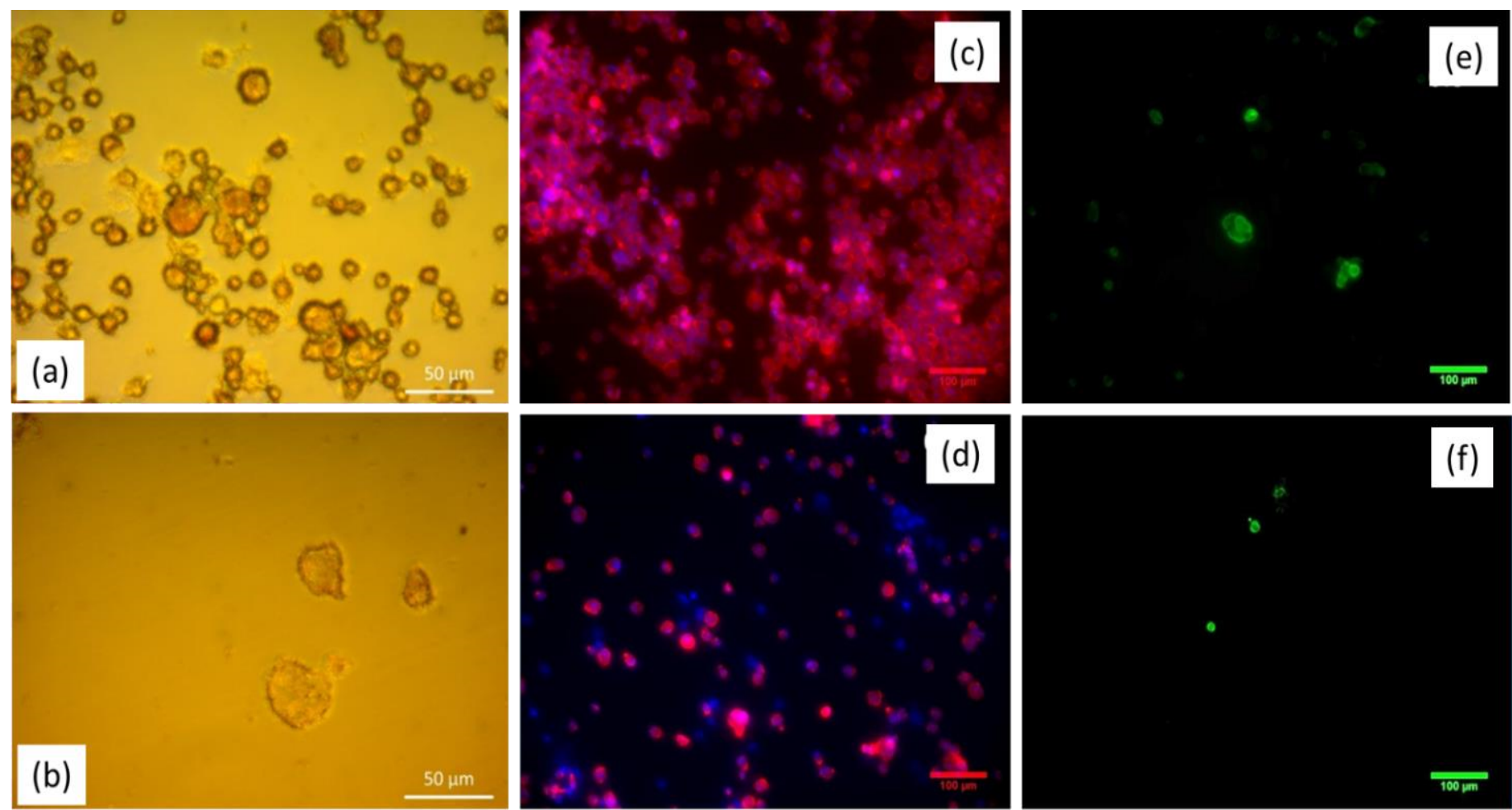

Figure 5. Light microscope images of cell morphology studies after osteoclast-like cells were exposed to $0.5 \mathrm{mg} / \mathrm{ml}$ of (a) Etidronate and (b) TrisPP. Fluorescent images of Actin ring staining of the same culture at $0.5 \mathrm{mg} / \mathrm{ml}$ of (c) Etidronate and (d) TrisPP. TRAP staining images of the same culture with the $0.5 \mathrm{mg} / \mathrm{ml}$ of Etidronate (e) and TrisPP (f). 

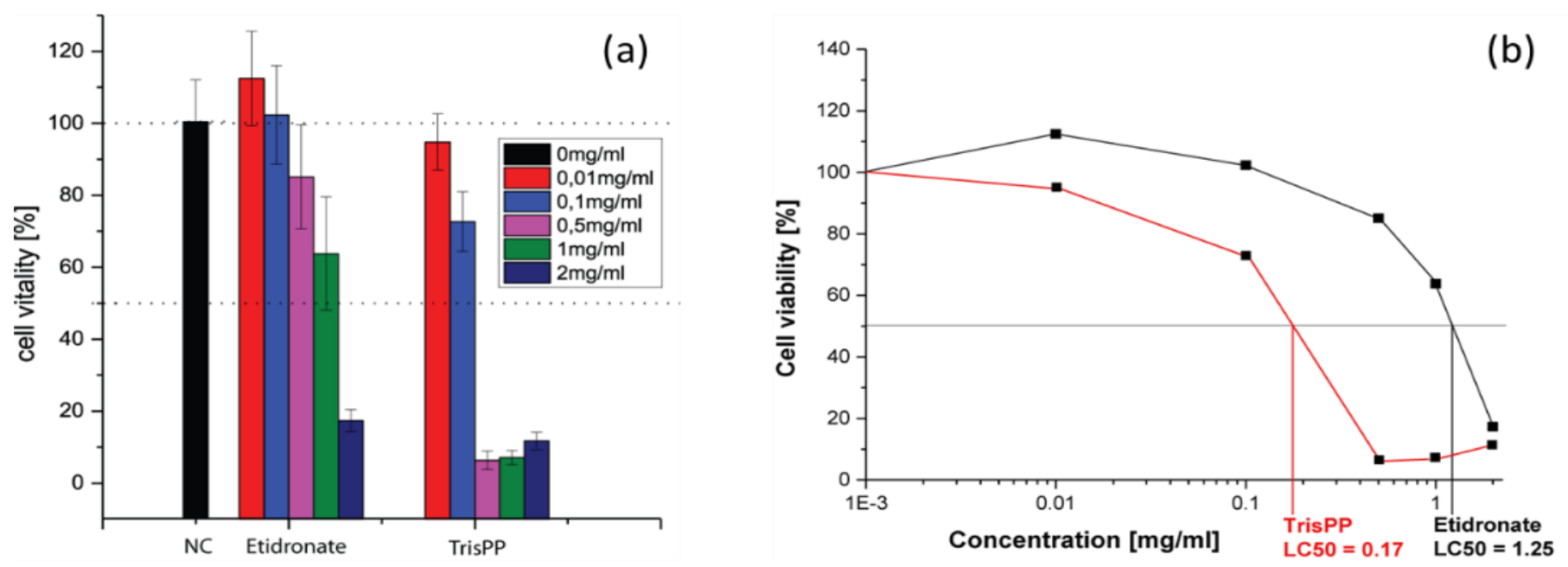

Figure 6. (a) Cell viability in osteoclast-like cells after 24 hours Etidronate and TrisPP treatments. (b) Lethal concentrations of Etidronate $\left(\mathrm{LC}_{50} 1.25 \mathrm{mg} / \mathrm{ml}\right)$ and $2,3,3-\mathrm{TrisP}\left(\mathrm{LC}_{50} 0.172\right.$ $\mathrm{mg} / \mathrm{ml}$ ) in osteoclst-like cells.

\section{Molecular ligand-protein docking simulation}

DockingSever (a web-based computer program) was used to perform ligand-protein docking simulation of the 2,3,3-TrisPP and human farnesyl pyrophosphate synthase (hFPPS) model. Among 100 docking results, the first set was selected as the most stable and adapted docking position, this is determined by the lowest binding energies collected from an independent calculation. As illustrated in Table 1, low and negative binding forces $(\mathrm{kcal} / \mathrm{mol})$ were obtained to achieve maximum interactions between the single 2,3,3-TrisPP ligand and amino acid units within the hFPPS protein (Figure 7a). Figure $7 \mathrm{a}$ also displayed the three major hydrogen bond formations via the $\mathrm{O}-\mathrm{-H}-\mathrm{N}$ and $\mathrm{O}-\mathrm{H}-\mathrm{-O}$ interactions involving two phosphoryl and a carboxylate unit in the 2,3,3-TrisPP ligand with the amide and carbonyl unit in the hFPPS protein. Moreover, calculations obtained from this simulation indicated further potential satisfying hydrogen bonding formations of the 2,3,3-TrisPP-hFPPS model (Figure $7 \mathrm{~b}$ ) can be achieved at amino acid sequence 174 (ASP), 193 (TYR), 196 (ILE), 197 (VAL), 200 (LYS), 201 (THR), 240 (GLN), 243 (ASP), 244 (ASP), 261 (ASP) and 266 (LYS).

\section{In vitro osteoblast assay}

\section{ALP activities}

Alkaline phosphatase (ALP) activities were used to identify and quantify osteoblast (MC3T3-E1) differentiation, data was collected at day 1, 3, 5 and 7 after treatments of different concentrations of Etidronate and 2,3,3-TrisPP $(0.01-2 \mathrm{mg} / \mathrm{ml})$ in the present of ALP reaction solution (figure $8 \mathrm{a} \&$ figure $8 \mathrm{~b}$ ). The results were obtained by measuring the absorbance $\left(\lambda_{\mathrm{abs}} 405 \mathrm{~nm}\right)$ of $p$-nitrophenol formation in osteoblast cultures. Figure 8 shows the ALP activities in osteoblasts after treatments of Etitronate (Figure 8a) and 2,3,3TrisPP (Figure 8b), high levels of ALP $\left(4.0 \times 10^{-7}-6 \times 10^{-7}\right)$ were recorded in most cases when comparing to the control groups. Only a slight drop $(<5 \%)$ was observed when cultures were exposed to $0.1 \mathrm{mg} / \mathrm{ml}$ of Etidronate and $0.01 \mathrm{mg} /$ $\mathrm{ml}$ of 2,3,3-TrisPP in day 3. A further decreased in the ALP level $(\sim 10$ $\%$ ) was observed after 2,3,3-TrisPP treatments at concentrations of 0.01 and $0.1 \mathrm{mg} / \mathrm{ml}$ in day 5 and 7 .

\section{Mineralisation potentials}

Mineralisation of MC3T3-E1 cells following treatment were studied over a period of 5 weeks, calcium formation in cultures
Table 1. Calculated binding energies from 2,3,3-TrisPP-hFPPS molecular docking simulations

\begin{tabular}{|c|c|c|c|c|}
\hline $\begin{array}{c}\text { EST. free energy } \\
\text { of binding }\end{array}$ & $\begin{array}{c}\mathrm{vdW}+\text { Hbond }+ \\
\text { desolv. Energy }\end{array}$ & $\begin{array}{c}\text { Electrostatic } \\
\text { energy }\end{array}$ & $\begin{array}{c}\text { Total intermolec. } \\
\text { Energy }\end{array}$ & Interact. surface \\
\hline$-4.73 \mathrm{kcal} / \mathrm{mol}$ & $-5.22 \mathrm{kcal} / \mathrm{mol}$ & $-0.43 \mathrm{kcal} / \mathrm{mol}$ & $-5.65 \mathrm{kcal} / \mathrm{mol}$ & 504.899 \\
\hline
\end{tabular}

were determined by tagging Alizarin Red stain, visualised under light microscope (Figure 9 top) and subsequently analysed using colormetric assay (Figure 9 bottom). The top microscopic images show selective osteoblast mineralisation process in the present of Etidronate (Figure 9a) and 2,3,3-TrisPP (Figure 9b) at different concentrations $(0.01-2 \mathrm{mg} / \mathrm{ml})$ in week $5 .^{\dagger}$ It is worth noting that 2,3,3-TrisPP at concentration $0.01 \mathrm{mg} / \mathrm{ml}$ exhibited optimum promotion in osteoblast mineralisation, as clear orange extracellular matrix nodules formation resulted from calcium deposits binding were observed. The highest calcium levels were measured at 1.3-1.5-fold changes ( $c a$. control $=1$ ) when MC3T3-E1 cells were treated with 0.01 and $0.1 \mathrm{~g} / \mathrm{ml}$ of 2,3,3-TrisPP for 5 weeks, hence 2,3,3-TrisPP at low concentrations significantly increased osteoblast mineralisation.

\section{Discussion}

\section{Cytotoxic effects of 2,3,3-TrisPP in osteoclast-like cells}

Preliminary cytotoxic studies were performed using differentiated osteoclastic cell line derived from mouse leukaemic monocytemacrophages (RAW264.7). This particular derivative has been identified as a transfectable RANK-expressing cell line that activates nuclear factor kappa B (NF-kB), osteoclastic phenotype and bone resorption. In vitro results obtained from cell viabilities (Figure $5 b$ ), actin ring study (Figure 5d) and TRAP expression (Figure 5f) from osteoclast-like cells showed different levels of toxic effects induced by 2,3,3-TrisPP at various concentrations $(0.01-2 \mathrm{mg} / \mathrm{ml}) .^{\dagger}$ When comparing results obtained from Etidronate treatments (Figure $5 \mathrm{a}, 5 \mathrm{c}$ and $5 \mathrm{e}$ ), a significant decline in osteoclastic activity was observed in all data collected upon treatments of 2,3,3-TrisPP at $0.5 \mathrm{mg} / \mathrm{ml}$ or above (Figure 5b, 5d and 5f). Fluorescent images (Figure 5d) obtained from actin study showed alteration in the cytoskeleton and some disruptions of the ruffled border suggested direct morphological changes in the osteoclast-like cells. Cell viabilities (Figure 6) of osteoclasts were determined by cell counting protocols, $[50,51]$ lethal concentration $\left(\mathrm{LC}_{50}\right)$ of 2,3,3-TrisPP calculated as 0.17 , which showed over 7 times 

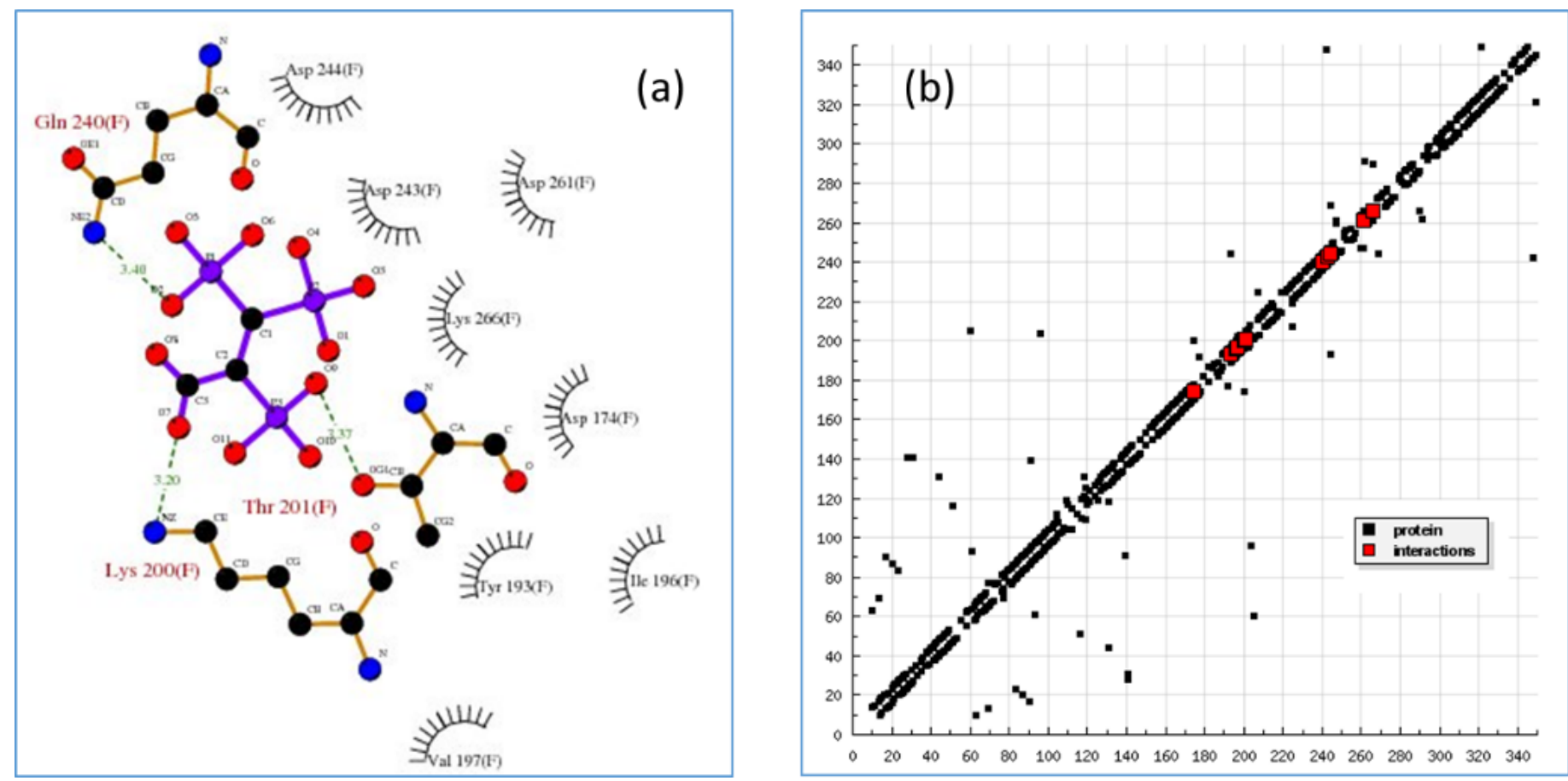

Figure 7. (a) Molecular docking 2D model (partial image) demonstrates binding interactions between 2,3,3TrisPP and amino acids involve in the hFPPS cavity, green dash lines indicate hydrogen bonding formations with calculated bond lengths. (b) Hydrogen bonding plot shows potential satisfying hydrogen bonding formation from 2,3,3-TrisPP and amino acids sequence present in hFPPS protein.

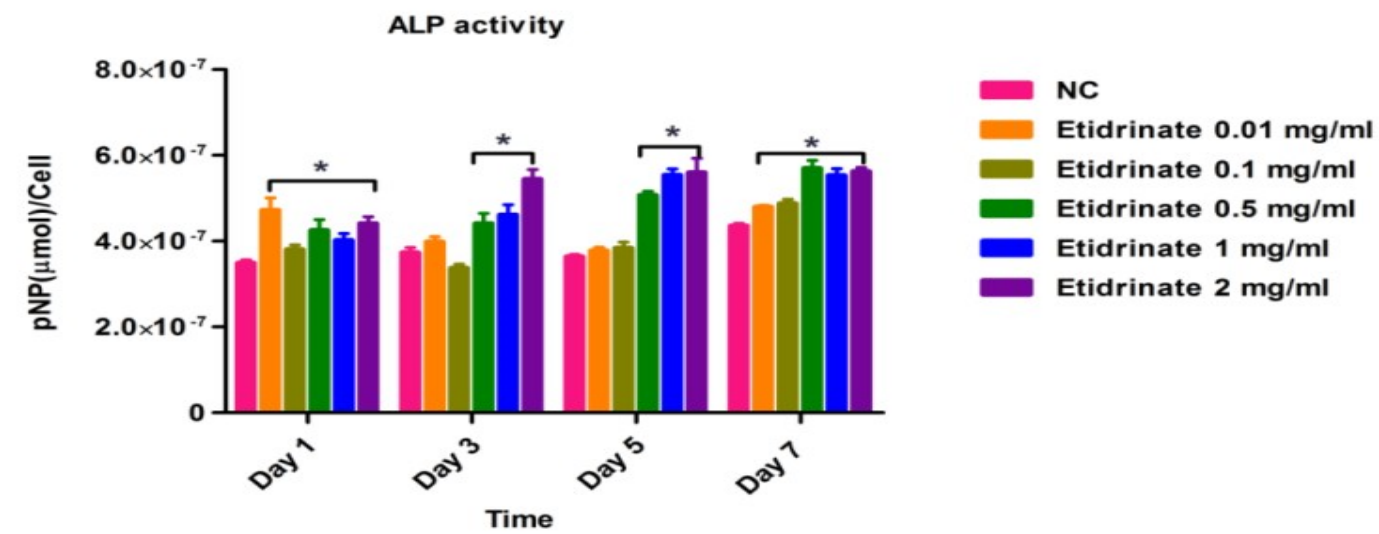

Figure 8a. APL activities were measured to quantify numbers of differentiated osteoblast cells under treatments of Etidronate.

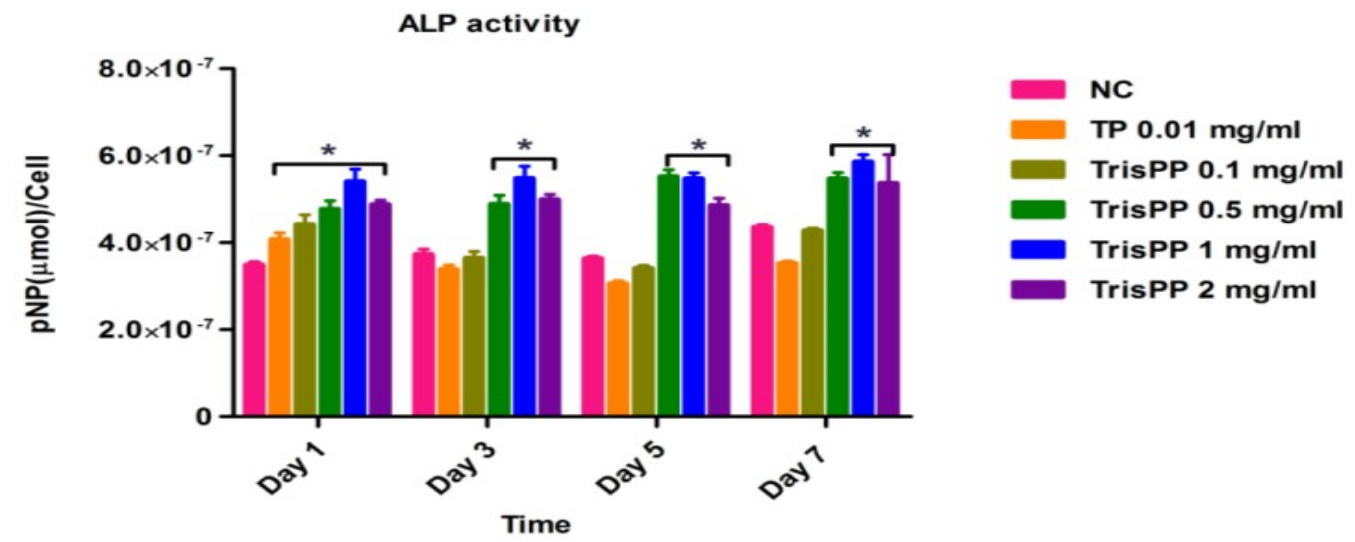

Figure 8b. APL activities were measured to quantify numbers of differentiated osteoblast cells under treatments of 2,3,3-TrisPP 
(a) Etidronate $(\mathrm{mg} / \mathrm{ml})$

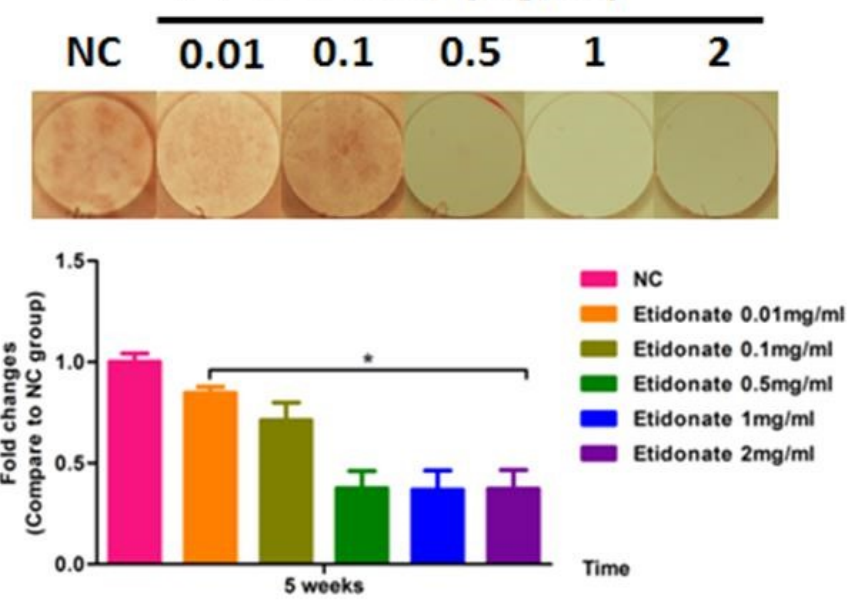

(b) TrisPP $(\mathrm{mg} / \mathrm{ml})$
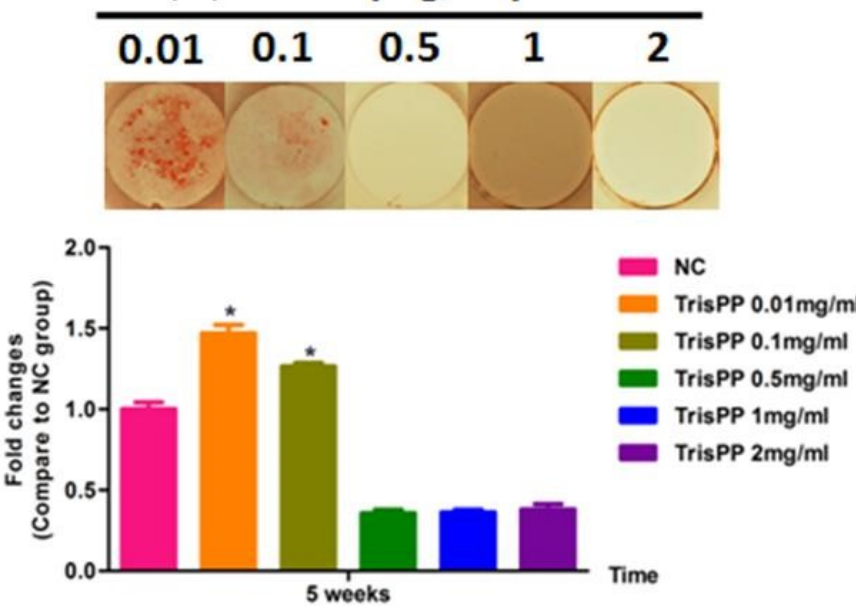

Figure 9. Mineralisation potential of osteoblasts (top) after MC3T3-E1 cultures were exposed to different concentrations (0.01-2 mg/ml) of Etidronate (a) and 2,3,3-TrisPP (b) for week 5. Orange nodules observed were due to calcium deposit and Alizarin Red binding. Quantitative analysis (bottom) of calcium formation via osteoblast mineralisation upon Etidronate and 2,3,3-TrisPP treatments after 5 week.

more cytotoxic effect to osteoclast-like cells than Etidronate (LC50 $=1.25$ ). Moreover, 2,3,3-TrisPP showed not only to exert cytotoxic effects in osteoclast-like cells, but it also appeared to inhibit their cell proliferation. Figure $6 \mathrm{~b}$ shows stages of osteoclasts proliferation over a period of 7 days and clearly indicates inhibitory effects on osteoclast recruitment/adhesion and shortened their life span upon 2,3,3-TrisPP treatments at concentration as low as $0.01 \mathrm{mg} / \mathrm{ml}$ in day 3 and onwards.

High binding affinity level calculated from human FPPS and 2,3,3-TrisPP models

Despite clinical BPs have been used as first line treatments for bone diseases in the last four decades, their molecular mechanisms of action have only become apparent in the last ten years $[10,52]$. There are two major pathways that have been generally recognised so far. ${ }^{11}$ It is known that non-nitrogen containing BPs inhibit osteoclast proliferation by interfering the ATP biosynthesis and leading to form a BP-metabolite analogue. An example of a BP-metabolite analogue formed by Etidronate is presented in figure 1 (structure on the right). Whereas $\mathrm{N}$-BPs induce osteoclast apoptosis by selectively binding to enzyme farnesyl pyrophosphate synthase (FPPS) and subsequently prevent the prenylation steps in cholesterol synthesis via the mevalonate pathway (Figure 2) [10-12].

Our computational docking simulation results obtained from the human FPPS protein model $(2 \mathrm{f} 7 \mathrm{~m})$ support the above theory. For example, when a N-BP (i.e. Ibandronate) was used as a ligand model, high binding affinity with un-liganded hFPPS protein was calculated, whereas no binding interaction was found when ligand model was replaced by non-nitrogen BPs (i.e. Clodronate/ Etidronate). Interestingly, such theory did not apply to our non-nitrogen containing 2,3,3-TrisPP when the same simulation method was applied. These are illustrated in 2D (Figure 7a) and 3D model (Figure 10) as 2,3,3-TrisPP fits into the hFPPS cavity perfectly and provides high level of docking interactions at minimal required binding energies (Table 1).

The additional phosphoryl unit located at the $\mathrm{C}$-atom adjacent to the bisphosphonate $\alpha$-Carbon in the 2,3,3-TrisPP provided a 'pendanteffect' (Figure 10b), which happens to have similar geometry to the highly potent N-BPs that is required to bind to FPPS enzyme. This is supported by data obtained from hydrogen bonding plot (Figure $7 \mathrm{~b}$,
$10 \mathrm{~b}$ and 10c), the amino acid sequences (i.e. Lys200, Thr201, Gln240) that are satisfactory for potential hydrogen bonding formation match well with binding locations obtained from crystallography in-situ data produced by other N-BPs analogues (i.e. Zolendronate) [41]. This suggests nonnitrogen containing 2,3,3-TrisPP may undergo dual molecular actions to inhibit osteoclastic activities: (1) by manipulating ATP metabolite formation to give the proposed analogue as drawn in figure 11 (right); (2) by binding to FPPS to prevent the mevalonate biosynthesis as proposed in schematic figure 11 (left)

\section{Osteoblast differentiation and mineralisation}

Bone metabolism is a constant dynamic process where osteoclasts are responsible for bone resorption and osteoblasts for bone formation. Therefore, the balance of osteoclasts and osteoblasts levels is crucial for bone repairing and regulating bone mineral density. Mineralisation process is an essential step for bone development and regeneration, it is a process when osteocytes are produced and where the basic scaffolds of hydroxyapatite are being formed. Recent studies have shown that some BPs are able to preserve osteoblast and osteocyte viability, [53] it is interesting that our 2,3,3-TrisPP also appear to have such capability toward the osteoblasts (MC3T3-E1) we used in this study. MC3T3-E1, a pre-cultured mouse cell line, is commonly used as a model for studying osteoblasts differentiation, because it has behaviour similar to primary calvarial osteoblasts. This cell line gives observable levels of osteoblast differentiation when it is treated with the growth osteogenic medium, it also forms a well mineralised extracellular matrix when it reacted with $\mathrm{Ca}^{+}$ions [54].

In our study, high levels of ALP activities (Figure 8b) in the osteoblastic culture were measured upon treatments with 2,3,3-TrisPP at all concentrations $(0.01-2 \mathrm{mg} / \mathrm{ml})$. This suggested cell had undergone a progressive osteoblast differentiations and that the process was not interrupted, but encouraged by the present of 2,3,3-TrisPP. Moreover, interesting data collected from the mineralisation potential study showing clear orange extracellular matrix nodules were formed and visualised (top right image in Figure9), this had also brought to our attention. The formation of intensive orange nodules (as illustrated in top figure $9 \mathrm{~b}$ ) were due to a collective binding of calcium deposits after labelling cells with Alizarin Red S stain in osteoblastic MC3T3-E1 

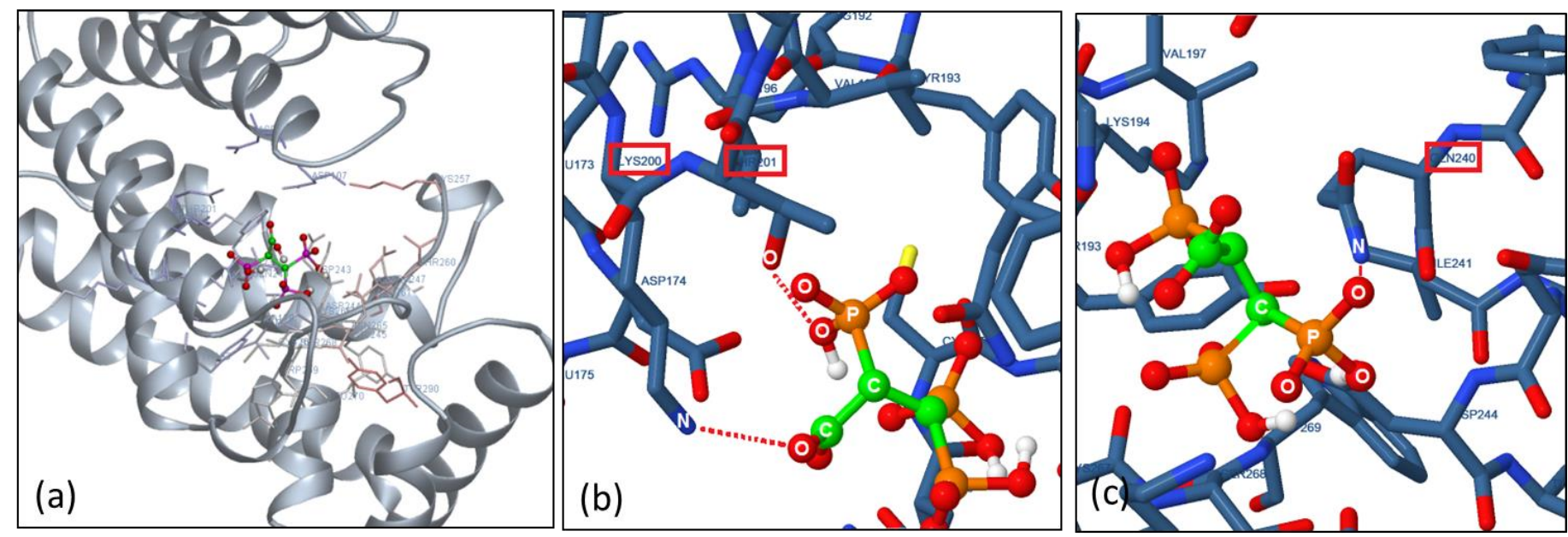

Figure 10. (a) 3D docking image in full showing the entire geometry of single ligand 2,3,3-TrisPP slotted into the centre cavity of the hFPPS macro-protein. (b) A zoomed in image showing hydrogen interaction $(\mathrm{O} \cdot \bullet \cdot \bullet \cdot \mathrm{O})$ between the oxygen atom located in the extra phosphoryl unit in 2,3,3-TrisPP with amidic oxygen in Thr201. (c) A zoomed in image shows hydrogen interaction $(\mathrm{O} \cdot \bullet \cdot \cdot \bullet \mathrm{N})$ involving an oxygen atom from the germinal bisphosphonate unit and a nitrogen atom from amide unit in Gln 240 .<smiles>CC(C)=CC[Po+]#[Os]</smiles>

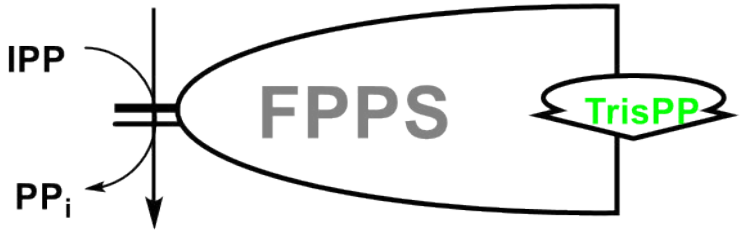<smiles>C/C(=C/CO[Pb])CC/C=C(\C)[Po]</smiles>

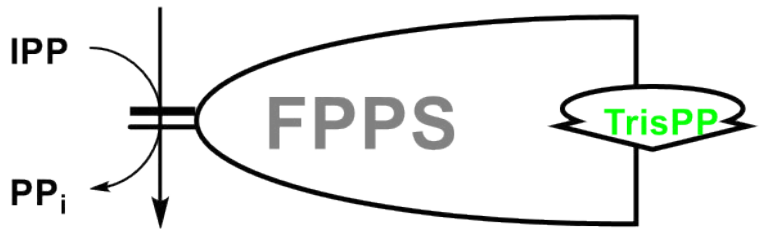<smiles>CC(C)=CCCC(C)=CCCC(C)=CCOP</smiles>

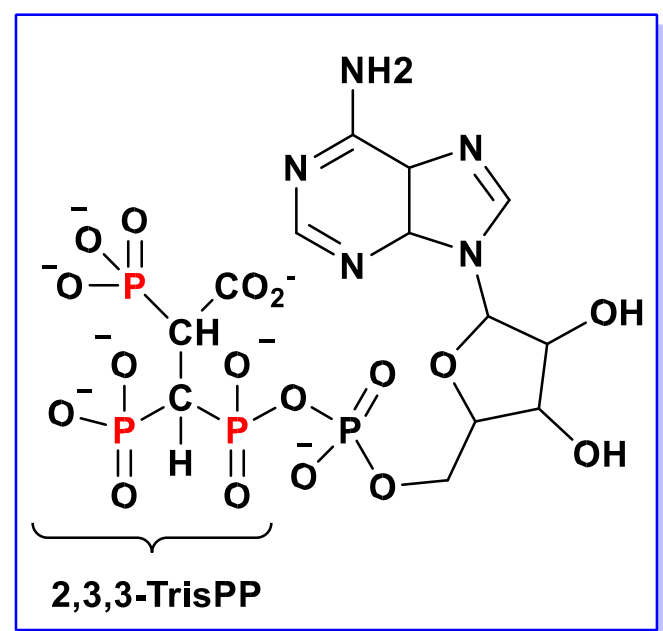

Figure 11. Proposed dual mechanistic actions of novel 2,3,3-TrisPP in osteoclasts involving manipulation of ATP biosynthesis (right) and inhibitory effect in FPPS enzyme in the mevalonate pathway (left).

cultures, which were incubated in $2,3,3$-TrisPP $(0.01 \mathrm{mg} / \mathrm{ml})$ for 5 weeks. In summary, 2,3,3-TrisPP at low concentrations $(0.01-0.1 \mathrm{mg} /$ $\mathrm{ml}$ ) showed to preserve cell proliferation, promote cell differentiation and facilitate mineralisation in osteoblasts, these evident suggested that novel 2,3,3-TrisPP can be used potentially to aid processes involving bone deposition and regeneration.

\section{Conclusions}

In general, we found the molecular chemistry of this 2,3,3-TrisPP and their derivatives are very interesting. The convenient syntheses of these compounds are worth highlighting, together with the chemical structures of these highly bulky systems, where multiple phosphoryl units are fitted in a close proximity would also an interest of spectroscopy chemists. Although not published, we also learnt from our extended study that these compounds is capable of forming organometallic complex with metals.

In our biological study, 2,3,3-TrisPP was found to exhibit inhibitory effect in osteoclastic cells over 7 times higher than the reference BP (Etidronate). Computational docking simulation suggested that 2,3,3-TrisPP may undergo more than one cellular pathways to inhibit the functions of osteoclast-like cells as proposed in schematic figure 11. We found that 2,3,3-TrisPP not only inhibited osteoclast activity, but it also promoted osteoblast differentiation and the latter mineralisation process. 
Overall, we found the molecular nature of these trisphosphonate systems are surprisingly diverse with respect to its chemistry and biology. The observed inhibitory effects in osteoclastic cells and the facilitation in osteoblastic mineralization exerted by 2,3,3-TrisPP treatments imply its potential applications in bone therapy, as it may help reducing bone resorption while promoting bone deposition. Therefore, it is worth investigate these compounds further to explore their biological and medical functions.

\section{Acknowledgements}

Authors would like to thank Dr.Mark Scott from the School of Pharmacy (University of Hertfordshire) for acquiring all the NMR results for this work. This work was supported in part by grant awarded from the Royal Academy of Engineering (RAEng.12/13RECI052) and the Engineering and Physical Sciences Research Council (EP/ N034368/1).

\section{References}

1. Russell RG (2011) Bisphosphonates: the first 40 years. Bone 49: 2-19 [Crossref]

2. Coughlan T, Dockery F (2014) Osteoporosis and fracture risk in older people. Clin Med (Lond) 14: 187-191 [Crossref]

3. Bolland MJ, Cundy T (2014) Republished: Paget's disease of bone: clinical review and update. Postgrad Med J 90: 328-331 [Crossref]

4. Clézardin P, Benzaïd I, Croucher PI (2011) Bisphosphonates in preclinical bone oncology. Bone 49: 66-70 [Crossref]

5. Fleisch H (2002) Development of bisphosphonates. Breast Cancer Res 4: 30-34. [Crossref]

6. Azuma Y (1995) Alendronate distributed on bone surfaces inhibits osteoclastic bone resorption in vitro and in experimental hypercalcemia models. Bone 16: 235-245. [Crossref]

7. Derenne S (1999) Zoledronate Is a Potent Inhibitor of Myeloma Cell Growth and Secretion of IL-6 and MMP1 by the Tumoral Environment. Journal of Bone and Mineral Research 14: 2048-2056 [Crossref]

8. Dieli, F (2007) Targeting Human T Cells with Zoledronate and Interleukin-2 for Immunotherapy of HormoneRefractory Prostate Cancer. Cancer research 67: 74507457 [Crossref]

9. Ebetino FH, Hogan AM, Sun S, Tsoumpra MK, Duan X, et al. (2011) The relationship between the chemistry and biological activity of the bisphosphonates. Bone 49: 20-33. [Crossref]

10. Fisher JE Alendronate mechanism of action: geranylgeraniol, an intermediate in the mevalonate pathway, prevents inhibition of osteoclast formation, bone resorption, and kinase activation in vitro.

11. Fisher JE, Rogers MJ, Halasy JM, Luckman SP, Hughes DE, et al. (1999) Alendronate mechanism of action: geranylgeraniol, an intermediate in the mevalonate pathway, prevents inhibition of osteoclast formation, bone resorption, and kinase activation in vitro. Proc Natl Acad Sci U S A 96: 133-138 [Crossref]

12. Rogers MJ, Crockett JC, Coxon FP, Mönkkönen J (2011) Biochemical and molecular mechanisms of action of bisphosphonates. Bone 49: 34-41 [Crossref]

13. Oldfield E (2010) Targeting isoprenoid biosynthesis for drug discovery: bench to bedside. Acc Chem Res 43: 1216-1226 [Crossref]

14. Cook M, Mani P, Wentzell JS, Kretzschmar D (2012) Increased RhoA prenylation in the loechrig (loe) mutant leads to progressive neurodegeneration. PLoS One 7: e44440 [Crossref]

15. Li L, Zhang W, Cheng S, Cao D, Parent M. (2012) Isoprenoids and related pharmacological interventions: potential application in Alzheimer's disease. Mol Neurobiol 46: 64-77 [Crossref]

16. Bonn D (2002) Scientists join smallpox vaccine controversy. Lancet Infect Dis 2: 515 [Crossref]

17. No JH (2012) Lipophilic analogs of zoledronate and risedronate inhibit Plasmodium geranylgeranyl diphosphate synthase (GGPPS) and exhibit potent antimalarial activity. Proceedings of the National Academy of Sciences of the United States of America 109: 4058-4063 [Crossref]
18. Jokiniemi J, Vuokila-Laine E, Peräniemi S, Vepsäläinen J. J, Ahlgrén M (2007) Structural study of metal complexes of bisphosphonate amide ester: copper, magnesium, zinc and cadmium complexes of (dichloromethylene)bisphosphonic acid P-piperidinium-P'-methyl ester. CrystEngComm 9: 158-164

19. Wang L (2006) A Biocompatible Method of Decorporation: Bisphosphonate-Modified Magnetite Nanoparticles to Remove Uranyl Ions from Blood. Journal of the American Chemical Society 128: 13358-13359 [Crossref]

20. Yang Z (2005) Self-assembly of small molecules affords multifunctional supramolecular hydrogels for topically treating simulated uranium wounds. Chemical Communications 35: 4414-4416 [Crossref]

21. Ogawa K (2005) Development of a Rhenium-186-Labeled MAG3-Conjugated Bisphosphonate for the Palliation of Metastatic Bone Pain Based on the Concept of Bifunctional Radiopharmaceuticals. Bioconjugate chemistry 16: 751-757 [Crossref]

22. Gibson AM (2003) Radiolabelled Bisphosphonates and method Great Britain patent

23. Martin de Rosales, R. T. 99mTc-Bisphosphonate-Iron Oxide Nanoparticle Conjugates for Dual-Modality Biomedical Imaging Bioconjugate Chem. 22: 455-465

24. Subramanian G, McAfee J. G. (1977). Bone-seeking technetium-99m complex. USA patent

25. Peter B (2005) Calcium phosphate drug delivery system: influence of local zoledronate release on bone implant osteointegration. Bone 36: 52-60

26. Tengvall P, Skoglund B, Askendal A, Aspenberg P (2004) Surface immobilized bisphosphonate improves stainless-steel screw fixation in rats. Biomaterials 25: 2133 2138 [Crossref]

27. Yoshinari M, Oda Y, Inoue T, Matsuzaka K, Shimono M. (2002) Bone response to calcium phosphate-coated and bisphosphonate-immobilized titanium implants. Biomaterials 23: 2879-2885 [Crossref]

28. Cohen-Sela E (2006) Alendronate-loaded nanoparticles deplete monocytes and attenuate restenosis. Journal of controlled release: official journal of the Controlled Release Society 113: 23-30

29. Demadis KD, Paspalaki M, Theodorou J (2011) Controlled Release of Bis(phosphonate) Pharmaceuticals from Cationic Biodegradable Polymeric Matrices. Industrial \& Engineering Chemistry Research 50: 5873-5876

30. Giger EV, Castagner B, Leroux J. C (2013) Biomedical applications of bisphosphonates. Journal of controlled release: official journal of the Controlled Release Society 167: $175-188$

31. Kumar V, Shahi A.K (2014) Nitrogen containing bisphosphonates associated osteonecrosis of the jaws: A review for past 10 year literature. Dent Res $J$ (Isfahan) 11: 147-153 [Crossref]

32. Graham DY (2002) Review: What the Gastreoenterologist should know about the gastrointestinal safety profiles of Bisphosphonates? Digestive Diseases and Sciences 47: $1665-1678$

33. Marx RE, Sawatari Y, Fortin M,Broumand V (2005) Bisphosphonate-induced exposed bone (osteonecrosis/osteopetrosis) of the jaws: risk factors, recognition, prevention, and treatment. J Oral Maxillofac Surg 63: 1567-1575 [Crossref]

34. Rodan GA (1998) Mechanisms of action of bisphosphonates. Annu Rev Pharmacol Toxicol 38: 375-388. [Crossref]

35. Ezra A, Golomb G (2000) Administration routes and delivery systems of bisphosphonates for the treatment of bone resorption. Adv Drug Deliv Rev 42: 175195. [Crossref]

36. Fulfaro F, Casuccio A, Ticozzi C, Ripamonti C (1998) The role of bisphosphonates in the treatment of painful metastatic bone disease: a review of phase III trials. Pain 78 : 157-169 [Crossref]

37. Widler L, Jaeggi KA, Glatt M, Müller K, Bachmann R, et al. (2002) Highly potent geminal bisphosphonates. From pamidronate disodium (Aredia) to zoledronic acid (Zometa). J Med Chem 45: 3721-3738 [Crossref]

38. Romanenko VD, Kukhar V P (2013) Methylidynetrisphosphonates: Promising C1 building block for the design of phosphate mimetics. Beilstein J Org Chem 9: 991-1001 [Crossref]

39. Smits JP, Wiemer DF (2011) Synthesis and reactivity of alkyl-1,1,1-trisphosphonate esters. J Org Chem 76: 8807-8813 [Crossref]

40. Griffiths DV, Benoit DM, Cheong YK, Duncanson P, Han X (2014) Novel ylidic phosphoryl compounds from halogenated furan-2,5-diones with trivalent phosphorus esters: application of this approach to new trisphosphonates containing a geminal bisphosphonate unit. Phosphorus, Sulfer, Silicon and other elements, special issue dedicated to Louis D. Quin 189: 1013-1027 
41. Li W, Cheong YK, Wang H, Ren G, Yang Z (2016) Neuroprotective Effects of Etidronate and 2,3,3Trisphosphonate Against Glutamate-Induced Toxicity in PC12 Cells. Neurochem Res 41: 844-854. [Crossref]

42. Rondeau JM, Bitsch F, Bourgier E, Geiser M, Hemmig R, et al. (2006) Structural basis for the exceptional in vivo efficacy of bisphosphonate drugs. ChemMedChem 1: 267273. [Crossref]

43. Bikadi Z, Hazai E (2009) Application of the PM6 semi-empirical method to modeling proteins enhances docking accuracy of AutoDock. Journal of Cheminformatics 11: $1-15$ [Crossref]

44. Morris GM (1998) Automated docking using a Lamarckian genetic algorithm and an empirical binding free energy function. Journal of Computational Chemistry 19: 1639.

45. Solis FJ, Wets RJB (1981) Minimization by Random Search Tehniques. Mathematics of Operations Research 6

46. Rago R, Mitchen J, Wilding G (1990) DNA fluorometric assay in 96-well tissue culture plates using Hoechst 33258 after cell lysis by freezing in distilled water. Anal Biochem 191: 31-34

47. Nishikawa M, Akatsu T, Katayama Y, Yasutomo Y, Kado S, et al. (1996) Bisphosphonates act on osteoblastic cells and inhibit osteoclast formation in mouse marrow cultures. Bone 18: 9-14 [Crossref]
48. Detsch R, Boccaccini AR1 (2015) The role of osteoclasts in bone tissue engineering. $J$ Tissue Eng Regen Med 9: 1133-1149 [Crossref]

49. Baron R, Ferrari S, Russell RG (2011) Denosumab and bisphosphonates: different mechanisms of action and effects. Bone 48: 677-692 [Crossref]

50. Hiroi-Furuya E (1999) Etidronate (EHDP) inhibits osteoclastic-bone resorption, promotes apoptosis and disrupts actin rings in isolate-mature osteoclasts. Calcif Tissue Int 64: 219-223. [Crossref]

51. Ikeda K (2011) [Mitochondrial function in bone resorption and formation]. Nihon Rinsho 69: 1203-1208. [Crossref]

52. Miyazaki T (2013) [Role of mitochondria in osteoclast function]. Clin Calcium 23: 1577-1583 [Crossref]

53. Brown JP, Morin S, Leslie W, Papaioannou A, Cheung AM, et al. (2014) Bisphosphonates for treatment of osteoporosis: expected benefits, potential harms, and drug holidays. Can Fam Physician 60: 324-333 [Crossref]

54. Bellido T, Plotkin LI (2011) Novel actions of bisphosphonates in bone: preservation of osteoblast and osteocyte viability. Bone 49: 50-55 [Crossref]

Copyright: $@ 2017$ Cheong YK. This is an open-access article distributed under the terms of the Creative Commons Attribution License, which permits unrestricted use, distribution, and reproduction in any medium, provided the original author and source are credited. 